Portland State University

PDXScholar

Criminology and Criminal Justice Faculty

Publications and Presentations

Criminology and Criminal Justice

$12-1-2020$

\title{
Juveniles in the Interrogation Room: Defense Attorneys as a Protective Factor
}

\author{
Caitlin N. August \\ Portland State University \\ Kelsey S. Henderson \\ Portland State University, kelsey.henderson@pdx.edu
}

Follow this and additional works at: https://pdxscholar.library.pdx.edu/ccj_fac

Part of the Criminal Law Commons, Criminology and Criminal Justice Commons, and the Psychology Commons

Let us know how access to this document benefits you.

\section{Citation Details}

August, Caitlin N. and Henderson, Kelsey S., "Juveniles in the Interrogation Room: Defense Attorneys as a Protective Factor" (2020). Criminology and Criminal Justice Faculty Publications and Presentations. 90. https://pdxscholar.library.pdx.edu/ccj_fac/90

This Post-Print is brought to you for free and open access. It has been accepted for inclusion in Criminology and Criminal Justice Faculty Publications and Presentations by an authorized administrator of PDXScholar. Please contact us if we can make this document more accessible: pdxscholar@pdx.edu. 
(C)American Psychological Association, 2020. This paper is not the copy of record and may not exactly replicate the authoritative document published in the APA journal. Please do not copy or cite without author's permission. The final article is available, upon publication, at:

https://doi.org/10.1037/law0000294

August, C. N. \& Henderson, K. S. (2020). Juveniles in the Interrogation Room: Defense Attorneys as a Protective Factor. Psychology, Public Policy, and Law. Advance online publication. http://dx.doi.org/10.1037/law0000294

\title{
Juveniles in the Interrogation Room: Defense Attorneys as a Protective Factor
}

\author{
Caitlin N. August and Kelsey S. Henderson \\ Portland State University
}

\section{Author Note}

Caitlin N. August and Kelsey S. Henderson, Department of Criminology \& Criminal Justice, Portland State University

We have no conflicts of interests to disclose.

This research was supported in full by an American Psychology-Law Society student grant in aid (2019). The authors wish to thank Dr. Mark Leymon and Dr. Mauri Matsuda for taking the time to review this work. As always, their feedback was constructive and detailed. Both Dr. Leymon and Dr. Matsuda helped improve our work, and for that we thank them. Selected findings were presented at the 2020 Oregon Criminal Defense Lawyers Association Juvenile Law Conference (virtual). 


\begin{abstract}
Juveniles are more susceptible in the interrogation room than adults, due to a host of vulnerabilities that put them at risk. Scholars have suggested that requiring the presence of a defense attorney during interrogations can protect juveniles from making an unintelligent waiver; variations of this type of policy have been mandated in some states across the United States (e.g., Illinois and California). The current study takes an exploratory, qualitative approach to examine how defense attorneys may act as a protective factor in the interrogation room. We interviewed 19 juvenile defenders using a semi-structured interview method; questions focused on experiences in the interrogation room, juveniles' waivers of rights, and protections for juvenile clients. Eight themes emerged that fit broadly into three categories: Factors related to juvenile defendants (e.g., dispositional youth susceptibility factors), the interrogation process and system (e.g., law enforcement impact), and safeguards in the system (e.g., requiring attorneys). Data from interviews suggest defense attorneys are rarely present when their juvenile clients are questioned, highlighting that juvenile defendants frequently waive their rights. Defense attorneys are cognizant that juveniles are susceptible to interrogation tactics, and are skeptical of the protection parents can provide in this context. Overall, defense attorneys are supportive of laws that require juveniles consult with an attorney prior to waiving their rights or require their presence in the interrogation room, but raise a number of logistical concerns, and offer possible solutions important for policy (e.g., an “on-call” attorney, or 'appropriate adult'). Keywords: Juveniles, interrogations, defense attorneys, Miranda warnings
\end{abstract}




\section{Juveniles in the Interrogation Room: Defense Attorneys as a Protective Factor}

In the United States, on any given day, roughly 60,000 juveniles are incarcerated in jails and prisons (America's Addiction to Juvenile Incarceration, n.d.). Juveniles are often thought of in terms of being a protected class; however, not all policies and procedures in the criminal justice system align with that assumption. For example, juveniles are subjected to interrogations no different from those of adults (Redlich, Silverman, Chen, \& Steiner, 2004). Accusatorial interrogation methods (commonplace in the United States) have been documented to increase the likelihood of false confessions, particularly among susceptible populations, such as juveniles (Kassin, 2014). This project explored one of the most highly endorsed recommendations for protecting juveniles in the interrogation room-requiring defense attorney presence.

In the United States, the vast majority of juvenile interrogations include no adult other than law enforcement officers. In one study of 307 youth, $90.2 \%$ were interrogated alone, with parents present in only $8.1 \%$ of the interrogations; in none of these interrogations was an attorney present (Feld, 2012). While there is value for parents to be involved in their child's legal decisions (Henning, 2006), evidence has shown that the presence of a parent or guardian in the interrogation room is not enough to prevent false confessions (Viljoen, Klaver, \& Roesch, 2005). Consider the five juveniles, convicted in the 1990s after each confessed to the rape of a female jogger in Central Park (known as the 'Central Park Five'; see Exoneration Anniversary: Central Park Five, 2012). Although there were parents and other family members present, all five juveniles independently made false confessions to the crime (Burns, Burns, McMahon \& Florentine Films, 2012).

Youth are particularly susceptible during an interrogation, as they are predisposed to be obedient to authority, have a greater dependency on adults, and lower maturity levels; factors 
which all contribute to the decision to waive one's Miranda rights, and puts juveniles at an increased risk for a false confession (Gudjonsson, 2018; Kassin, Drizin, Grisso, Gudjonsson, Leo, \& Redlich, 2010; Robin, 1982). In a comprehensive list of 'personal risk' factors related to false confessions, Gudjonsson lists 'youth', and other factors related to juvenile vulnerabilities such as 'not understanding Miranda rights', 'developmental disorders', 'delinquent peers', 'cognitive abilities', and 'absence of support during interviews' (2018; p. 115-116). Globally, rates of self-reported false confessions among juveniles range from $0 \%$ (Icelandic sample) and 6\% (English sample) to 23\% (United States sample) (as cited in Gudjonsson, 2018, p. 107). Estimates from the National Registry of Exonerations suggest that $38 \%$ of crimes allegedly committed by juveniles involved a false confession during the interrogation (as cited in False Confessions More Prevalent Among Teens, 2013). The rate of false confessions among youth raises the question of whether it should be required that juveniles have a defense attorney or 'appropriate adult' present in the interrogation room.

Illinois and California recently passed laws that require attorney involvement before/during questioning (these laws are crime-type dependent; Public Act 099-0882, 2017; 395 Welfare and Institutions Code $§$ 625.6). For example, California’s Senate Bill 395 states that youth 15 years and younger must consult with an attorney in person, by telephone or video conference before an in-custody interrogation can take place and prior to the waiving of one's Miranda rights (395 Welfare and Institutions Code $\S$ 625.6). While these statutory mandates may be considered a step forward in protecting juveniles from making an unintelligent waiver of their rights, many other states do not have such laws. In Oregon, a similar bill was raised in 2017 (House Bill 2718), which would have required youth to speak with an attorney (in person, over the phone, or video conference) prior to waiving their rights. This consultation could not be 
waived and would precede any waiver of rights and a custodial interview. Ultimately, this bill did not pass. However, a recent report by the National Juvenile Defender Center listed appointing "all youth a qualified juvenile defender prior to any interrogation or interview by law enforcement or the juvenile department" as a key recommendation to improve access to counsel and representation in Oregon (2020). This, coupled with other states passing laws on this issue raises the question of the benefits of requiring an attorney to be present during juvenile interrogations. This project seeks to address this gap by examining how defense attorneys act as a protective factor for juvenile defendants in the interrogation room.

\section{Juvenile Interrogations and Confessions}

In 1964, the United States Supreme Court (USSC) held that defendants have a $6^{\text {th }}$ Amendment right to counsel during interrogations (Escobedo v. Illinois). Miranda (1966), extended Escobedo by mandating that suspects must be told of their rights, and failure to do so is a violation of defendant's $5^{\text {th }}$ Amendment protection against self-incrimination. Years later, these due process protections were extended to juveniles (In re Gault, 1967). The USSC went so far as to caution about juvenile confessions, stating, the "authoritative opinion has cast formidable doubt upon the reliability and trustworthiness of 'confessions' by children" (In re Gault, 1967). Similarly, the more recent ruling in J.D.B. v. North Carolina (2011) recognized the role age plays in interrogations, and that a juvenile may feel bound to submit to questioning when an adult would not. Therefore, officers must consider a juvenile's age when determining whether he or she is "in custody", and Miranda requirements and protections apply. While these legal decisions solidified the right to an attorney in the interrogation room, the question remains of whether juveniles possess the legal understanding to appreciate and invoke this right.

\section{Police Interrogation and Interview Tactics}




\section{United States versus International}

Appreciating and invoking the right to an attorney becomes all the more important in a system that uses accusatorial interrogation techniques, with a presumption of guilt. The Reid Technique is the most commonly used interrogation method in the United States; it is a nine-step process, which can involve confronting suspects with evidence of their guilt, developing themes as justifications of criminal acts, and handling the denials of suspects (for more information see Inbau, Reid, Buckley, \& Jayne, 2001). And, a field study from a sample of Canadian interrogations demonstrate that officers draw on these same tactics in their interviews, albeit selectively using various components and not the full nine-steps (e.g., changing the theme if a suspect continued to reject theme; King \& Snook, 2009). The Reid Technique manual largely instructs police officers to use these same themes with juvenile suspects (Inbau et al., 2001).

It is not altogether surprising then that police officers in the United States are trained and report using the same interrogation tactics on juveniles and adults (Cleary \& Warner, 2016). Although officers self-reported using certain techniques more frequently with adults than with juveniles, the overall pattern of usage was similar for adults and juveniles. For example, on a scale of 1-never to 5-always, mean frequency of use for building rapport for adults was 4.12 and juveniles 3.67 , and minimizing the seriousness of the offense 2.98 for adults and 2.75 for juveniles. In another sample, there were no significant differences in the frequency with which police reported using tactics such as deceit, presenting false evidence, and minimizing the seriousness of the crime, between adult and juvenile suspects (Meyer \& Reppucci, 2007). A third of police officers surveyed endorsed the need for additional training on issues related to juveniles (Meyers \& Reppucci, 2007). In the United States, police officers are given little instruction about interrogating juveniles, so they often fall back on the strategies learned in training, which were 
likely intended for adult suspects. Collectively, self-reports from police officers in the United States suggest juveniles are interrogated like adults (Meyer \& Reppucci, 2007), and while these tactics might be considered comparatively benign for adults, research suggests juveniles do not respond to these tactics like adults.

In contrast to the interrogation practices in the United States, the PEACE model, used in the United Kingdom, New Zealand, and Norway (Gudjonsson \& Pearse, 2011), differs from the Reid technique in that it is not guilt-presumptive, less confrontational (Kassin et al., 2010), and was designed to take into consideration vulnerabilities of suspects, such as age, and minimize the likelihood of false confessions (Shawyer, Milne, \& Bull, 2009). Officers trained in the PEACE model avoid the use of leading questions, "heavy pressure", and are not authorized to lie to suspects or present false evidence (Gudjonsson \& Pearse, 2011). These are important distinctions in light of research suggesting juveniles are more likely to falsely confess, even internalize guilty behavior, when presented with falsified evidence (Redlich \& Goodman, 2003). Under the

PEACE model, juveniles, vulnerable because of their age, should have access to "an appropriate adult" whose main responsibility is to provide advice and ensure that the interview is conducted fairly (Kassin et al., 2010). More on 'appropriate adults' below.

\section{Juvenile Legal Decision Making}

One of the biggest concerns regarding juveniles in the interrogation room is whether they possess the level of comprehension and understanding to make a knowing and intelligent waiver of their rights. In the United States, Miranda was seen as a protection for defendants, however, the language used requires at least a sixth-grade education to comprehend $75 \%$ of the warnings, and a ninth-grade education to fully understand all components of the Miranda warnings (Rogers, Hazelwood, Sewell, Shuman, \& Blackwood, 2008). Similarly, in a sample of juveniles 
in Canada, the average percent of information correctly retained from youth waiver forms was $14.53 \%$, with students in higher grade levels recalling more than those in younger grades levels (Freedman, Eastwood, Snook, \& Luther, 2014). This poses an issue for all juvenile defendants, and a critical one for younger defendants who may not be at the same cognitive level as older juveniles, let alone adults. Older adolescents with lower intelligence levels might have sufficient understanding, but it is less likely that younger adolescents, regardless of intelligence, comprehend the legal language (Viljoen \& Roesch, 2005). Because of this gap, some jurisdictions have modified their Miranda warnings to be more on par with juvenile comprehension levels (e.g., King County Sheriff’s office).

Not only might juveniles have difficultly comprehending, but actions such as officers nodding their head while reading the Miranda warnings may have an effect on decisions (Feld, 2012). These types of behaviors are more influential for juveniles who have lower levels of psychosocial maturity (Steinberg, 2007), which makes them more persuadable to outside influence (such as an interrogator) and puts them at an increased risk to make impulsive decisions. Studies suggest that in calculating the risk-reward ratio that guides decision making, adolescents may discount risks and calculate rewards differently than adults (Gardner \& Steinberg, 2005). In fact, juveniles under the age of 16 are more likely than adults to make decisions that reflect a propensity to comply with authority figures (Grisso et al., 2003). Younger juveniles are more compliant in nature than older juveniles/young adults (Gudjonsson, Sigurdsson, Sigfusdottir, Asgeirsdottir, González, \& Young, 2016; Redlich \& Goodman, 2003). For example, in one study, when presented with false evidence, $50 \%$ of college students falsely confessed, in comparison to $73 \%$ of those who were 12 to 13 years old, and $88 \%$ of those 15 to 16 years old (Redlich \& Goodman, 2003). In addition, when shown evidence that they had 
committed a crime, though they had not, youth 12 to 16 years old were more likely than college students to take responsibility for the act. Lower comprehension levels and increased compliance threaten the assumption of the effectiveness of the Miranda safeguard for juveniles, and puts juveniles at a greater risk of falsely confessing.

Lower cognitive abilities (Viljoen \& Roesch, 2005) and psychosocial maturity (Steinberg, 2007) contribute to difficulty in understanding and participating in legal proceedings, which can contribute to a waiver of rights. Viljoen and Roesch (2005) found that cognitive ability was an important predictor of legal capacities across 11 to 17 -year-old defendants. In particular, cognitive ability was a strong predictor of juveniles' understanding of interrogation warnings and effectively communicating with their attorney (e.g., interpreting information, asking questions). This lack of comprehension contributes to a high waiver rate; roughly $90 \%$ of juveniles waive their right to an attorney and to remain silent (Rogers et al., 2008). Defendants who waive their rights are younger and have less understanding of their rights than those who exercised their rights (Viljoen et al., 2005). Without assistance from a defense attorney, youth are at a heightened risk to make an unintelligent and involuntary waiver of their rights.

\section{‘Appropriate Adults' versus Defense Attorneys}

In the United States, juveniles are often interviewed alone, and if an adult is present, it is most likely the parent; because of this, the Reid interrogation manual has specific instructions for parents to sit, not speak, and act only as an observer (Inbau et al., 2001). Due to these instructions and a lack of legal knowledge, a parent's presence in the interrogation room may be detrimental to the juvenile suspect (Redlich, Silverman, Chen, \& Steiner, 2004). Juveniles do not typically ask to involve their parents, and if they are involved, their advice might run counter to that of the juvenile's attorney. Viljoen et al. (2005) found that of 152 juvenile defendants, none 
said that they wanted a parent present for questioning. In another study, despite being in the room next door, only seven of 64 juveniles asked to speak with their parents before signing a confession statement (Redlich et al., 2004). Parents often indicate that they want their child to confess to the crime, not knowing if they are, in fact, guilty or innocent. In a sample of 30 juveniles questioned by the police with their parents present, none were advised by their parents to invoke their rights, and rather, half reported that their parents wanted them to confess (Viljoen et al., 2005). In the United States, juveniles are responsible for requesting assistance (whether it be their parent or defense attorney), rather than a policy of required presence. As many juveniles do not request their parent or defense attorney's presence, adding that level of protection as a requirement might prove a more effective safeguard.

\section{The Role of Appropriate Adults}

In the United Kingdom, juveniles are interviewed with the assistance of an appropriate adult, who is an independent individual, instructed to ". . . to advise the interviewee, observe whether or not the interview is being conducted properly and fairly, and facilitate communication with the interviewee" (Home Office, 1985, Code C, p. 83). Appropriate adults have a distinct role from legal representatives (analogous to the role of an attorney in the United States), the former has a general duty to protect vulnerable suspects, and the latter is primarily concerned with legal strategy (Medford, Gudjonsson, \& Pearse, 2003). Importantly, appropriate adults can be family members or friends (lay appropriate adults), and this is more likely to be common in interrogations involving juveniles; social workers or trained volunteers are more common in vulnerable adult interrogations (Medford et al., 2003).

In an analysis of a sample of United Kingdom interrogations, appropriate adults (both lay and professional) made appropriate interventions, and fulfilled their responsibilities of 
facilitating communication (e.g., ensuring the suspect understood the officer's questions), ensuring that the interview was conducted fairly, advising the suspect (e.g., reminding them of their legal right to an attorney and not to sign any documents they did not understand), and protecting the suspect (Medford et al., 2003). This analysis also found that appropriate adults made inappropriate interventions such as: taking on the role of the investigating officer, insisting the suspect tell the truth, or challenging the suspect's account. Importantly, while lay appropriate adults were found to have made more appropriate interventions, they also made more inappropriate interventions than professional (trained) appropriate adults. Additionally, the presence of an appropriate adult affected officer behavior; with officers adopting a more "considered and fair" approach to interviewing in the presence of an appropriate adult (Medford et al., 2003, p. 262). Overall, while there are positive effects of appropriate adults, extensive training and independence from the suspect likely impact the efficacy of this role.

\section{The Role of Defense Attorneys}

The American Bar Association has issued specific guidelines for juvenile defenders, falling under the USSC's stance that "kids are different" (as discussed in Miller v. Alabama, 2012). These guidelines note, "Juveniles are less likely to waive their rights or further incriminate themselves if they consult with counsel first and counsel properly advises them of their rights" (American Bar Association, 2013). However, as established in Berghuis v. Thompkins (2010), an interrogation can continue unless and until the suspect has affirmatively and unequivocally invoked their rights (Gottesman, 2012). This places the burden on the juvenile to invoke their right to an attorney. In one study, of the 114 defendants questioned by the police, 9.65\% requested an attorney, and only one of those defendants reported that their attorney was present for questioning (Viljoen et al., 2005). 
Somewhat similar, in the United Kingdom, detainees have an "unequivocal right to free legal advice", and solicitors provide support, and also ensure that individuals' rights are protected (Pearse \& Gudjonsson, 1997, p. 200-201). In a sample of 161 interrogations, solicitors or legal representatives were present in $56 \%$ of interviews, which the authors note as evidence of an upward trend of legal advisor presence directly following the interrogation policy reforms of the early 1990s (Pearse \& Gudjonsson, 1997). However, adults (with and without the assistance of an appropriate adult) were more likely to exercise their right to have legal representation present than juveniles (Medford et al., 2003). Furthermore, individuals made fewer confessions/admissions when a legal advisor was presented compared to not (adult sample, Pearse \& Gudjonsson, 1997).

Research suggests that juveniles simply having contact with their attorney increases their understanding of the legal process. Viljoen and Roesch (2005) found that those juveniles who met with their attorney were better able to understand police interrogation procedures and the criminal justice process (e.g., understanding their rights, case adjudication). Juveniles benefit from attorney involvement. In light of research highlighting juvenile susceptibility, requiring a defense attorney to be present in the interrogation room may act as a protective safeguard against false confessions, and decisions that would be outside the scope of knowing and intelligent. We explored how defense attorneys can interact, engage, and protect juvenile clients in the interrogation room by going directly to the source.

\section{The Current Study}

The current body of research on juveniles in the interrogation room focuses more on estimator variables such as comprehension of Miranda rights, suggestibility, and lack of legal understanding. There is less information on system variables (i.e., factors the system can control 
such as policies and procedures), which contribute to juveniles' waiver decisions (with and without an attorney present). To our knowledge, this study was the first of its kind to explore defense attorneys' perception of juveniles' responsivity and behavior in the interrogation room, their legal decision-making, and system safeguards such as a defense attorney presence requirement. As this was an exploratory study, we made no apriori hypotheses. However, extensive research indicates that juveniles have lower legal understanding, and are more likely to waive their Miranda rights and confess (Freedman et al., 2014; Gudjonsson et al., 2016; Redlich \& Goodman, 2003; Rogers et al., 2008; Viljoen et al., 2005; Viljoen \& Roesch, 2005).

Therefore, we expected that defense attorneys would generally be supportive of requiring an attorney in juvenile interrogations. Furthermore, we expected to uncover themes regarding defense attorneys' perceptions of their role and the importance of legal representation (e.g., sharing legal knowledge), and the role of appropriate adults and parents in interrogations.

We used semi-structured interviews to explore this topic from defense attorneys' vantage point. The interviews were conducted to facilitate a discussion of when the attorney is brought in as counsel, and experiences with juvenile clients who have been interrogated (with and without their presence). We chose to examine this topic through the perspective of defense attorneys, as per the United States' adversarial system and legal precedent, they are charged with protecting their clients' rights. Because defense attorneys have legal knowledge and experience with youth clients, their perspective is most ideal for this topic in comparison to other legal actors. By asking about the attorneys' experiences and opinions (e.g., on interrogation tactics and juveniles' legal understanding), we can examine the attorney as a protective factor in the interrogation.

\section{Method}

\section{Recruitment and Participants}


Defense attorneys who represented juvenile defendant clients, defined as anyone under the age of 18 , in the state were eligible to participate. Defense attorneys who had not previously represented a juvenile client were not included in this study. Attorneys were recruited through the statewide lawyer's association membership directory, online listings, and snowball sampling by word of mouth. The sampling population was restricted to only include defense attorneys with experience practicing law in Oregon in light of the recent bill (House Bill 2718). Additionally, we did not want to introduce any confounds by interviewing attorneys in different states, which likely have different waiver mechanisms, Miranda warning practices, and statutes guiding juvenile interrogations.

In total, roughly 119 juvenile defense attorneys were invited to participate in this study. Eligible participants were identified through the statewide defense organization membership directory, using the filter, 'juvenile'. We received 21 emails/responses indicating the recipient was not available (e.g., out on leave), only handles dependency or civil cases, or was not the right fit to participate based on the study goals (e.g., had not represented a juvenile client for a while). Additionally, we searched for juvenile criminal defense attorneys practicing in the state that were not included on the membership directory. Participants were sent an email about the study's goals and procedures, asking for their involvement. Lastly, an email was sent out through the statewide juvenile law listserv and committee. Participants were informed that their participation was voluntary, and no identifying information would be collected (i.e., names would not be connected with data).

The final sample consisted of 19 defense attorneys practicing in the state of Oregon (we used saturation of response to guide data collection). Participants were given the option of answering three demographic questions; all agreed to respond. Of the 19 total participants, 12 
identified as female (63.2\%). All but two participants identified as white (89.5\%). This is consistent with the racial/ethnic breakdown of lawyers in the U.S.; $86.6 \%$ are Caucasian, yet the percentage of female attorneys was higher than the nationwide percentage of $36.4 \%$ (U.S. Department of Labor, 2019). Of the two defendants who did not identify as white, one identified as Asian, and the other as Mexican-American. Among the 19 participants, the average years of experience practicing law was 23.5 years $(\min =$ five and $\max =48$ ). While participant attorneys were not specifically asked about the jurisdiction they practiced in or the type of firm they worked at (private vs. public defense services), this information was recorded in field notes. Of the 19 defense attorneys who participated, 13 were public defenders $(68.4 \%)$, and the other six private defense attorneys (31.6\%). Defense attorneys practiced in various jurisdictions across the state, all determined to be urban (Urbanized Areas and Urban Clusters, 2010).

\section{Procedure}

The Portland State University Institutional Review Board approved all materials and procedures involved in the collection of these data. Participants took part in a roughly 30-minute, semi-structured interview, which was audio recorded for the purpose of transcribing. The interviews focused on the defense attorney's perceptions of juvenile clients' abilities and level of legal understanding in the interrogation room (i.e., ability to make an informed waiver of rights), general experiences with juvenile clients who have been interrogated (with and without attorney presence), and opinions regarding a policy which would require a defense attorney in the interrogation room. Twelve participants requested to be interviewed over the phone (63.2\%), and seven participants requested the interview be conducted in person at their offices (36.8\%). Participants were compensated with a $\$ 40$ Amazon gift card. Three participants requested their compensation be donated to local non-profits, and one participant declined compensation. 


\section{Dependent Variables}

These data consist of responses from defense attorneys who represent juvenile clients; importantly, to ensure confidentiality, questions did not ask for any specific case information. There were a total of nine questions, with multiple follow-up questions. Follow up questions allowed for elaboration or probing of responses. We also asked three questions about demographics and professional experience (see Appendix). The questions were general (e.g., "If your juvenile client was considering waiving their $5^{\text {th }}$ Amendment right and confessing, how would you advise them?"). Nothing was asked that could violate attorney-client privilege.

\section{Data Analysis and Interpretation}

We specifically targeted 'group characteristics' (defense attorneys), where we selected defense attorneys "to create a specific, information rich group that can reveal and illuminate group patterns" (Patton, 2015, p. 528). As such, we used an inductive approach to discover patterns, themes, and categories in our data, and then illuminate key issues identified by participants within our group. Using an inductive approach allowed the themes from the data to come together based on participant responses, rather than fitting responses into themes derived from questions participants were asked (Braun \& Clarke, 2006).

As our analytic approach was inductive, we chose to allow categories, patterns, and themes to emerge (called, 'open coding'; Patton, 2015; Strauss \& Corbin, 1998). We chose not to make assumptions about participant responses as we were not testing a specific theory, and there is a lack of prior research on defense attorneys' perceptions of juveniles' behavior and system protections in the interrogation room. This study was exploratory, leading to the use of manifest coding. Manifest coding is preferred for exploratory research because it takes participant responses at face value and does not leave room for interpretation (Braun \& Clarke, 2006). We 
give a descriptive account of defense attorneys' reported experiences and perceptions of juvenile interrogations and safeguards, but make no inferences about implied meaning or theories about the "how" and "whys". Our iterative approach proceeded as follows.

All audio interviews were first transcribed verbatim, using Express Scribe Pro. Once transcribed, we used a thematic analysis using ATLAS.ti software. Using this software allows for codes to be selected in participants' responses and then compared across participants. Based on codes, themes were identified and patterns organized in participant responses using a six-phase process. After the transcription, the second phase involved reading through each interview, lineby-line, and taking notes about possible codes (e.g., parental influence, juvenile's competency to waive their rights, attorney's impact). Codes were inductive, coming directly from the data. Once discrete codes were created, the next step in this thematic analysis was to go through each transcribed interview using the ATLAS.ti software and code participant responses. After coding the interviews, a total of 115 codes were identified; two researchers worked to consolidate and sort into eight unique themes. Theme generation/code organization was primarily driven by prior literature and key issues on juvenile susceptibilities in the interrogation room (e.g., dispositional risk factors such as willingness to waive their rights), the interrogation process and room itself (i.e., situational risk factors such as influence of external pressures), and enacted or proposed policies/ reforms of safeguards in the interrogation room (e.g., requiring presence of an attorney).

After establishing themes, the codes placed into each theme were then reexamined for internal homogeneity and external heterogeneity, ensuring that the data in each theme fit in a meaningful way and there were clear distinctions between each theme (Braun \& Clarke, 2006). After this step, several codes were removed as they were only present in two or fewer interviews, some codes were removed from participant responses as they were determined to not fit, and 
others combined with other codes. As a result, 101 final codes remained and were sorted into the eight final themes. In the final phase, themes were named and defined. See Table 1 for final codes and their placement within themes.

\section{Results}

Interviews were semi-structured and not all participants were asked the same questions. Lack of participant agreement or response on a question or topic does not indicate that the attorney disagreed or ignored the prompt, but rather that it did not come up organically during the conversation. Table 2 displays the frequency of codes in each theme by participants. In Table 2, the number of times codes within each theme were referenced is depicted (e.g., dispositional youth susceptibility factors and requiring attorneys in the interrogation room were the most referenced themes). In referencing Table 2, it should be noted that some themes had more codes than others. In total, the following eight themes were identified: situational factors (i.e., factors related to the interrogation context), dispositional youth susceptibility factors, parental impact, requiring attorneys (i.e., a system factor-related response), law enforcement impact, opinions on safeguards, waiver competency, and system impact (i.e., factors related to the criminal justice system). In the following sections, a description is given for each theme accompanied by a breakdown of the findings.

\section{Factors Related to Juvenile Defendants}

Defense attorneys frequently commented on juveniles' developmental and cognitive susceptibilities; they also identified factors unique to juvenile defendants.

\section{Dispositional Youth Susceptibility Factors}

This theme includes factors identified by defense attorneys that have an impact on youth's ability to intelligently waive their Miranda rights due to individual characteristics. 
Examples include: not realizing the consequences of a waiver, lack of confidence in asserting their rights, being conditioned to be honest, and not understanding legal nuances. A common response from defense attorneys was that youth do not understand the long-term consequences of their actions $(N=12,63.2 \%)$, but rather just want to go and will say what they need to to leave $(N=7,36.8 \%)$. Defense attorneys referenced youth having brains that are not fully developed, which impacts their decision making $(N=13,68.4 \%)$. Of the 19 defense attorneys interviewed, 15 discussed youths' diminished reasoning ability or lower mental capacity (78.9\%). Another identified factor was that youth do not understand the legal nuances involved in their cases $(N=$ $13,68.4 \%$ ), and $73.7 \%$ of attorneys stated youth do not understand the Miranda warnings ( $N=$ 14). Attorneys described this issue as not that juveniles do not understand the words in the warnings, but they do not appreciate the context and meaning behind them:

Because when you think about it in context, when kids are, how do kids learn the word silence? It's mostly in school where that's the rule. You know, a teacher says silence, you know, 'Silence, be quiet, um as long as I'm talking and when I stop talking then you can ask your questions and you can talk.' That's how they learn the word, that's the context that they learn the word. They don't know all of the ramifications of the definition of the word so they put it into that context.

Another common statement by defense attorneys was that youth are conditioned and socialized to tell the truth, and importantly, they are never allowed to make "big" decisions like waiving one's rights $(N=11,57.9 \%)$. Juveniles believe they will get in trouble if they do not tell the truth, and do not appreciate the trouble that can sometimes come from talking (cooperating):

...They're kind of taught, from the school, and I think from an early age, a lot of people are taught that if you at least tell the truth you'll be fine. Um, and, albeit that's kind of a moral code, and that's something in regards to honesty and so forth. Kind of admitting your mistakes but it's different in a criminal setting in that, you sort of bypassing that fundamental principle of our democracy that the government's role or duty to prove you're guilty beyond a reasonable doubt... and so, that, and that's part of Miranda obviously. And that's really not explained to them so they don't really get that.

\section{Waiver Competency}


This theme encompasses defense attorney perspectives on the frequency of waivers and admissions, and juveniles' general competency of their rights. Defense attorneys reported that juveniles frequently waive their right to an attorney, and admissions are often made before the attorney even receives the case $(N=14,73.7 \%)$. Four attorneys reported that admissions are always made by juveniles (21.1\%). Defense attorneys stated that part of what contributes to youths' frequent waivers is their lack of perspective on long-term consequences: ...I'm often surprised if I get a police report that says, from my teenage client, 'I don't want to talk to you, I want to see my lawyer,' and that's because they don't understand that what they're saying has long term effect (sic) on them. And I think, that's the piece. There is, a lot of people talk, adults talk, juveniles talk, like people don't, I mean they just do. But, juveniles just I think, talk more. Because they don't think about in the moment like, you know, admitting to breaking into that, you know, convenience store when it was closed and stealing money from the register or whatever, I don't think they realize that that's a felony that's gonna (sic) follow them for ' $\mathrm{X}$ ' number of years or forever and could impact their ability to be in the military, or to access certain schools, or anything. And I just think, that's the bigger thing is; they're usually, teenagers are very shortsighted as far as what's happening is right in front of them. So they're not necessarily thinking about a decade from now when I'm going to be applying for college, I'm gonna (sic) have to check boxes that say like, 'I've been arrested for a felony.' And then they're going to have to explain it.

Twelve attorneys stated that youth are not competent to waive their rights $(63.2 \%), 5.3 \%$ said youth are competent to waive their rights $(N=1)$, and $31.6 \%$ said youth are sometimes competent to waive their rights $(N=6)$. In discussing competency of waivers, many defense attorneys referenced juveniles' understanding and appreciation of the role of an attorney. While $26.3 \%$ stated they felt youth are familiar with attorneys $(N=5)$, the majority, $57.9 \%(N=11)$, felt that youth are unfamiliar with the role of attorneys. They reported that sitting down and explaining to youth what their job is tends to help clear up any confusion. However, some youth still have difficulty grasping the role of the attorney (even after this conversation):

Um, some do and some do, you know, pretty quickly once it's explained. Um, andthen there are some who um, even after they've been sort of oriented to what it means to have a lawyer and what a lawyer can do for them, still would struggle to really appreciate what 
it means or to be empowered to use that person. Um, so again, I think it's sort of multilayered, it's um, I would say though that probably, unless they've had the opportunity to work with a lawyer before, um probably a large percentage of them don't really understand what that means.

\section{The Interrogation Process and System}

When considering how juveniles react and respond during the interrogation and questioning process, it is important to understand that juveniles are in a new context with pressure exerted from several directions. Defense attorneys pointed to parents, law enforcement, and the criminal justice system as being the cause of some of that pressure.

\section{Situational Factors}

This theme encompasses factors that have an impact on juveniles' waiver decisions due to factors outside their control, such as the context of the interrogation and questioning. Defense attorneys cited the circumstances around a case such as the case facts and evidence $(N=14$, $73.7 \%)$ and the severity of the charges $(N=6,31.6 \%)$, as important in considering juveniles' waiver decisions. Defense attorneys referenced that these factors not only influence juveniles' willingness to waive their rights and cooperate with the police, but also affect how they advise their juvenile client:

Oh gosh, off the top of my head, I think I would want to read the police reports, I would want to know the severity of the charges. I think I would like to know a little bit about my clients functioning. I would want to know, some of it again, depends on how severe the charges are because like the juvenile system? In theory, well, it's supposed to be able to be rehabilitative and punishment, you know what I mean? So like, there are options for rehabilitation within the juvenile system that aren't in the adult system, right? So kids are gonna (sic) be charged with a Measure 11 offense, or what would now be waived to adult court. You know I think that's a much different conversation so I guess those are some of the things I would want to think about. I also would want, I think you would wanna (sic) think about the law, whatever the case law is, may or may not apply in this situation. Oh gosh. You would want to know if there's codefendants. I guess you would want to know some of the circumstances surrounding the case. 
Defense attorneys also noted that situational factors, such as how much time the youth was given to make a decision $(N=5,26.3 \%)$ and where they were questioned $(N=9,47.4 \%)$, affect how likely youth were to waive their rights. More specifically, seven attorneys stated that youth are often questioned at school (36.8\%), which can be very influential for juveniles as it introduces another authority figure and level of discipline:

But I mean, there is this sense that when you're in school and the principal is asking you or your teachers are asking you or the school resource office is asking you, you are required at school to be obedient. You're required to listen to your teachers and the authority figures and that's been instilled in you since kindergarten. And so I think that the idea that the questioning is happening at school, um, is significant.

\section{Law Enforcement Impact}

This theme references the impact of law enforcement and includes: law enforcement having a different perspective than attorneys, acting as an authority figure, interrogation tactics, and cooperating with law enforcement. Defense attorneys commented that the goal of law enforcement is to identify a suspect, and the tactics that they use might have an undue influence on juveniles (e.g., "good cop, bad cop"; $N=18,94.7 \%$ ). The majority of attorneys discussed the effect police have on youth, as they are perceived as an authority figure $(N=15,78.9 \%)$. In addition, $89.5 \%(N=17)$ of defense attorneys noted that the level of pressure exerted during an interrogation impacts juveniles' willingness to waive their rights. For example, one defense attorney discussed the impact of police as authority figures and how that influence can play out with parents and interrogation techniques:

...Kids are going to be more apt to um, bend to an adult authority. They're more patterned to do that already, school administration, vice-principal, discipline officer, parents, you know, parents standing by, by the door when the officer comes to the door of the house to talk to the kid, and the parents say, 'You're gonna (sic) talk to the officer. Kid's not gonna (sic) say, 'Oh geez, Dad's gonna (sic) be not amused if I don't do what the officer says.' They're much more apt to make statements in those circumstances... But the interrogation techniques, there's so many variations on a theme. But a lot of times with the kids, it doesn't take much more than saying, 'Well we just 
wanna (sic) get your side of the story' that seems to be common. 'You know, we think we know what happened already, but you know, we'd like to get your side of the story, maybe it's something different.' Yeah, so it seems very innocent but, you also have situations where officers want polygraphs, and that's generally in sex offenses where, or in more serious type cases, but especially in the sex offenses. And the result of the polygraph may not be as important as the process surrounding it that involves the pre-test interview and the post-test interview. Which is essentially a disguised interrogation, trying to get statements from the person doing the polygraph. So, there's a lot of abuses of that by police departments and how they handle that whole process. It's not a larger percentage of cases but with sex offense it's certainly something that comes up.

Due to the adversarial nature of the U.S. legal system, police have a different perspective on interrogating juveniles and Miranda rights than attorneys $(N=16,84.2 \%)$. However, defense attorneys noted that, depending on the conditions, speaking with law enforcement can be beneficial for their juvenile clients $(N=11,57.9 \%)$, and they can use it as an opportunity to find out how much the police know about the case $(N=6,31.6 \%)$. Defense attorneys highlighted the possibility of using attorney presence to tilt the balance in the interrogation room:

I think law enforcement is not likely to want that, simply because the lawyer could shut it down, and say, 'We're making no statements tonight officers, write your report and we'll set up an interview once we have the information.' And that takes away the power imbalance that's there. And it would potentially put the child in a better negotiating position or in a position where, what the police really needed to make the case was some type of admission and they're not going to get it that night or that day.

\section{Parental Impact}

This theme highlights the role parents have on their child's behavior in the interrogation room, including: how parents have their own interests in mind, the frequency of parental presence during questioning, and the different roles that attorneys and parents play. Of the 14 attorneys who referenced parental presence in the interrogation room, six attorneys, or $42.9 \%$, stated that parents are not often present, four stated that parents are sometimes present (28.6\%), and four stated that parents are often present (28.6\%). Fourteen attorneys discussed the effect that 
parents can have; five believed that parents could be helpful (35.7\%) and nine felt that parents hurt their child's case $(64.3 \%)$.

And I've even had cases where I have parents or I've heard parents tell young people 'Oh you don't need an attorney, this is gonna (sic) be fine' or whatever. Or parents who maybe even motivated to have their child taken into detention or whatever or don't think that they want to apply to potentially have to be on the financial hook to reimburse the costs of a court-appointed attorney. Um, so I've even seen parents kind of act in a way that can be hindering.

Parents frequently advise their child to tell the truth to law enforcement $(N=15,78.9 \%)$.

Attorneys also said that parents sometimes have their own interests in mind $(N=10,52.6 \%)$, for example being more concerned with how their child's behavior will make them or their family

look. The parent's role can be further complicated if they are the victim of the accused crime,

feel responsible for discipline, or lack understanding of the legal process:

So I think that you have at least some parents who A, might be the victim of whatever the kid is accused of doing or B, might be so fed up with the situation of the kid not listening or not doing what the parent wants them to do that the idea that law enforcement is enticing to the parent because they're wanting that help and assistance in managing their child's behavior. Um and so I think some amount of parents would maybe be motivated to have the kid get in trouble or to be caught up in the system. So that's some, probably not all of them. I think you have some well-intentioned parents who also don't really fully appreciate the meaning of Miranda and the protections that our Constitution provides and so you get these parents that are like 'Oh Johnny just tell them what happened and this will all blow over,' and they don't understand, perhaps, the serious of what it means for a youth to talk to law enforcement and um, I think those are probably the two major risks.

\section{System Impact}

This theme includes factors about the criminal justice system that have an impact on juvenile defendants, such as issues with how the Miranda warnings are written, differences between juvenile and adult courts, and that the system is stacked against youth. Attorneys discussed the differences youth experience when going through the juvenile court system, rather than the adult court system $(N=7,36.8 \%)$ such as differences in the severity of consequences, 
and the ability to work with counselors in the juvenile court system. Several attorneys referenced issues with how the Miranda warnings are written $(N=11,57.9 \%)$ and how that contributes to juveniles' lack of understanding of its content, but also allows attorneys to dissect the case law around it. Attorneys additionally talked about how the system is stacked against juveniles as they have a unique position as defendants $(N=6,31.6 \%)$, who unlike adult defendants, receive punishment from not only the justice system but also from school, and their parents:

The general pattern you'll see is the...child will start in the administrative office and then they'll call the police, and the police will come into the administrative office and then it'll be a lot different in that, the administrative office. Even if the administrative office did interrogate them, to basically do the rigamarole to the police and the police would have to call the child's parent "Like look, we'd like your child to come in for questioning about this incident, you know, how about Tuesday at five?"

\section{Safeguards in the System}

After considering youths' susceptibilities in the interrogation room, defense attorneys advocated for juvenile-specific system safeguards.

\section{Opinions on Safeguards}

This theme generally included suggestions on safeguards for youth in the interrogation room, including: videotaping interrogations, increased time frame to make decisions, presence of a neutral adult in the room (e.g., 'appropriate adult'), and support for defense attorney presence as a requirement (this was more specifically teased out in the 'requiring attorneys' theme). In discussing various safeguards that may be helpful, attorneys listed body cams $(N=4,21.1 \%)$, a statute to make juvenile statements inadmissible $(N=2,10.5 \%)$, providing more support for defense attorneys $(N=2,10.5 \%)$, giving youth more time to decide on waiving their rights $(N=$ $4,21.1 \%)$, providing students with education on the criminal justice system and their rights $(N=$ $3,15.8 \%)$, videotaping interrogations $(N=15,78.9 \%)$, and specialized youth training for attorneys $(N=1,5.3 \%)$. The majority of attorneys discussed the benefits of requiring 
videotaping as it allows attorneys to review the questioning, and compare the video footage to

their client's and the police officer's account:

Sometimes recording and video are some safeguards for more information so that if an officer on a stand is making one representation how the child was or looked or whatnot, um, as a defense attorney I would absolutely want to listen to the conversations and see the video because showing that to my client would often give me or help that child refresh you know, 'I had peed my pants, I was sitting here and they wouldn't let me use the restroom until I had finished talking.' You know, stuff that you wouldn't necessarily know but the video might give you information about. So I think; generally, recording and video can be good. And then the question again is, do they have the full conversation before the waiver on recording or are they just, 'You just waived, I'm turning on the recording.' So it's really, do they have the full context which would be helpful, not just the confession that's being recorded.

Seventeen of the 19 attorneys interviewed were supportive of requiring defense attorney

presence while youth are questioned $(89.5 \%)$.

You know, if that were, imagine in a world where that were standard practice. Even telling a juvenile you have the right to an attorney, one will.... I think that they're not paying attention, that they don't see that as a real option, they're not paying attention to the words, to the meaning, they don't feel empowered to use that as a legit option. Like wait, stop everything, find me an attorney. I mean I've just never, as a public defender, heard of that happening, right? They just, those are just words that are said maybe or maybe not. And when they are said, they're said in an intense moment where someone is already feeling completely powerless and they become sort of meaningless, really. They're sort of rendered meaningless by the entire situation; I've never as a public defender, seen a juvenile assert that right. So if it were actually, common, required practice that okay, you sit here and we're going to go get an attorney for you and you can't talk to us until an attorney is present. Yeah, that takes all the onus of the young person to try in this situation that's chock-full of imbalance of power, and threat and fear, it would take all the burden off them. I mean, that would be pretty incredible!

Almost half $(N=8,42.1 \%)$ were uncertain about the helpfulness of an 'appropriate adult' (also called 'allied adult', or a neutral adult), such as a community member (with or without legal training) or a youth advocate similar to those assigned in dependency cases. Some expressed concerns that an appropriate adult may encourage the truth, as parents sometimes do $(N=3$, 15.8\%). Yet, $26.3 \%$ were hopeful that an appropriate adult might be beneficial as it puts an adult in the room to assist youth in making decisions $(N=5)$ : 
So you know, if you have a neutral person who is a lawyer or perhaps even a paralegal in the criminal law and understands certain things then they can say 'Hey maybe that's not a good idea, maybe you need to talk to a lawyer' kind of thing. Um, that would be better than having you know, just any old volunteer...

I mean I would imagine, I mean I'm certain people can be trained. I don't necessarily think it requires an advanced degree but I certainly don't think a parent who's emotionally invested in trying, often trying to uphold like a moral compass on top of everything else is the right person to have there.

\section{Requiring Attorneys}

This theme highlights defense attorneys' thoughts on the role that defense attorneys play in the interrogation room, their unique experience and legal knowledge, and how defense attorneys can assist and protect juveniles. Some examples include advising clients on the best course of action, empowering youth to make informed decisions, requesting a youth evaluation, and building a relationship with juvenile clients. Many of the attorneys emphasized that they are there to help their juvenile clients make informed decisions $(N=13,68.4 \%)$. In this study, onethird of attorneys (31.6\%) reported needing more time with their juvenile clients $(N=6)$. Attorneys also noted that a common consideration with juvenile clients is working to suppress statements given to the police during questioning $(N=17,89.5 \%)$ :

So in private work people can contact an attorney and they can generally speaking, get involved sooner and maybe try to be present during an interrogation or to negotiate before even charges are filed. In public defender work, those lawyers, we don't come on board until charges are filed so it kind of cuts off, there are options that aren't available anymore. So once a statement has been made, there's you know, there's always a look at whether those statements can be suppressed, were they made legally, what was the situation, was there custody, what was the level of interrogation? All that kind of thing, what's the mental status of the person who made the statement. So there's angles to look at, just trying to suppress that statement and not have it be considered evidence.

In this sample, $42.1 \%$ of defense attorneys reported that they have rarely been present while their juvenile client was questioned or interrogated $(N=8)$, and $57.9 \%$ reported that they had never been present for a juvenile interrogation $(N=11)$. Importantly, the majority of defense 
attorneys stated that they first meet their juvenile clients after charges have been filed $(N=18$, 94.7\%). If the juvenile hires a private criminal defense lawyer to represent them, they likely have earlier initial contact, and there is a stronger likelihood of the attorney being present for questioning. Whereas if the defense attorney is appointed by the court, the initial point of contact is later (after a court appearance), and it is unlikely that the defense attorney would be present for questioning. This scenario is further described in the above quote.

When considering how defense attorneys advise their juvenile clients, $94.7 \%$ said that they would advise their clients not to speak with police $(N=18)$. Nine attorneys said that they would wait to speak to law enforcement until they had more information about the case and had spoken with their client (47.4\%). Eight attorneys noted that they would advise their juvenile client to talk with law enforcement in a structured interview $(N=8,42.1 \%)$, which would allow the defense attorney to be there to supervise questioning, guide the conversation, and gather information from the officers about the evidence. By being present, they could not only witness what the police officer says but watch their client's reaction and hear their responses. This structured setting would give the attorney the opportunity to speak with their client beforehand, advise them about their options, and how to proceed if they decide to speak with the police. This puts the attorney in a better position to monitor the situation and protect their client:

It keeps them honest, it keeps it a conversation and not you know, where they're trying to intimidate or threaten or trick them into saying things that they don't want to say. And also, before we sat down with the police officer, I informed my client of what he was about to do and what those consequences would be, you know. And then knowing that and if you don't talk to the police, here's what they have. You know, so and then he also hears my opinion about whether he should talk to the police or not. And plus, um, before they talk to the police, now it depends on the circumstances, if it's that they've just been arrested and they've called me and I won't have as much time, but I will certainly talk to my client about how to answer, how to conduct himself during the interview, don't try and pull one over, if you're gonna (sic) talk to the police then you tell the truth butyou tell the truth only to this crime. 


\section{Discussion}

Extant research has demonstrated that juveniles are at an increased risk of waiving their rights (Rogers et al., 2008), are more susceptible to police interrogation tactics (Redlich \& Goodman, 2003), external pressures from police and parents, and have poorer legal understanding and comprehension (Viljoen \& Roesch, 2005). One recommendation to protect juveniles in the interrogation room is to require a defense attorney's presence before or during questioning (Alberts, 2016). Some states (e.g., California and Illinois) have passed laws that put

this practice into place, and others have considered similar bills (e.g., Oregon). This was the first study to our knowledge to explore the topic of a policy requiring defense attorneys in the interrogation room; we did this by conducting interviews with defense attorneys to better understand their experiences working with juvenile clients, and how defense attorney presence could protect and assist juveniles during questioning.

\section{Juvenile Decision-making and Miranda Waivers}

This study demonstrates that among juvenile defense attorneys, youths' susceptibility during the interrogation and their increased risk of waiving their rights, is an issue. The majority of defense attorneys in this sample stated that youth are not competent to waive their rights (consistent with NeMoyer, Kelley, Zelle, \& Goldstein, 2018); this is understandable given that Miranda warnings are written at a higher reading level and are heavy in legal jargon (Freedman et al., 2014; Rogers et al., 2008). Defense attorneys are cognizant that juvenile defendants struggle to comprehend the substance and meaning of Miranda, which makes it easier to waive those rights. The waiver rate for juveniles is high; in some jurisdictions, 80-90\% of juveniles waive their right to an attorney because they do not understand the meaning of the word "waive" (OJJDP, 2004). And 57.9\% of defense attorneys in this study reported that in their experience, 
juveniles are not familiar with the role of an attorney. Other research has found that $90 \%$ of youth waive their right to remain silent (Rogers et al., 2008), and 69\% go on to falsely confess (Redlich \& Goodman, 2003). In this study, 73.7\% of defense attorneys reported that by the time they receive the case, the juvenile client has frequently waived their rights and offered an admission or incriminating statement to the police.

All attorneys gave several reasons as to what makes youth more susceptible to waiving their rights. The most referenced justification was that youth are only concerned with short term goals; $63.2 \%$ of defense attorneys in this sample said juveniles are short-term oriented, and $36.8 \%$ said that they would say whatever they need to leave the interrogation. This is supportive of prior research noting that juveniles struggle with long-term decisions because they do not consider the future like adults do and instead focus on the short-term consequences or rewards (Steinberg, 2007). Juveniles' decision-making is characterized by an 'immaturity of judgment' that leads them to be impulsive, focused on the present, and diminished in their capacity to perceive risk (Owen-Kostelnick, Reppucci, \& Meyer, 2006). These dispositional risk factors are compounded by high prevalence rates of attention deficit hyperactivity disorder among juveniles, which is associated with compliance (Gudjonsson, Sigurdsson, Bragason, Newton, \& Einarsson, 2008; Young, Moss, Sedgwick, Fridman, \& Hodgkins, 2015). In its totality, these factors put juveniles at risk in the interrogation room. Defense attorneys were aware of the risks of juveniles' impulsive decision-making; most often, this was referenced in conjunction with their willingness to comply with their parents and law enforcement officers.

\section{Interrogation Setting}

The Role of Law Enforcement and Interrogation Tactics 
An important theme that emerged from defense attorneys is the different perspective and role of law enforcement in the interrogation room. Attorneys discussed how police officers have a different goal than that of the youth in the interrogation room. Because juveniles do not comprehend this, the tactics used by law enforcement, along with the impact of their authority figure status, make juveniles more likely to cooperate and offer an admission (sometimes against their best interests). Additionally, defense attorneys referenced situational factors that affect juveniles' waiver decisions, such as time constraints and the location of the interrogation.

The vast majority of defense attorneys in this sample $(89.5 \%)$ referenced the level of pressure police officers exert on juveniles as a factor of their waiver. This exertion of pressure is likely to have a stronger effect on juveniles than adults, given juveniles' short-term focus and willingness to comply. In this study, $78.9 \%$ of defense attorneys referenced how a law enforcement officer's authority figure status carries a powerful effect. Due to lower levels of psychosocial maturity, juveniles are more likely to comply with authority figures. Defense attorneys stated that law enforcement is not the only source of external pressure; a large percentage of defense attorneys noted that juveniles are often questioned at school in the presence of a school administrator or resource officer. This corresponds with defense attorneys' concerns that because juveniles are often raised to respect authority figures, this might increase willingness to comply, especially if they perceive there might be consequences at school as well.

Similarly, defense attorneys noted parents as an additional external pressure, and questioned the role they play in their child's case. In this study, $47.4 \%$ of defense attorneys stated that parents hurt their child's case, and 78.9\% reported that parents encourage their children to "tell the truth" to law enforcement. Defense attorneys reported that parents may advise their children to waive their right to an attorney, encourage them to cooperate, and even 
adopt an adversarial attitude toward their own kids. Defense attorneys noted that requiring a defense attorney to be present during the interrogation could help to even out this imbalance, to tilt the power dynamic back in favor of the youth.

\section{Safeguards in the Interrogation Room}

The data presented in this study are supportive of past research in that juveniles are often questioned and interrogated alone (estimates range from $73.7 \%$ to $90.2 \%$; Cleary, 2014, Feld, 2012). As such, it is essential to enact policies and practices that mandate safeguards in the interrogation room. In this study, there was strong support for both video recording of juvenile interrogations and requiring a defense attorney to be present during questioning. Defense attorneys stated that having a video recording of the interrogation assists in suppressing evidence by checking the recording against the police report and their client's account of what took place. This is an important tool for defense attorneys, as the majority stated that filing Motions to Suppress statements is common practice when representing juvenile clients.

In discussing juveniles' susceptibilities in the interrogation room, the vast majority of defense attorneys were supportive of policies requiring a defense attorney be present during juvenile interrogations. Defense attorneys were also supportive of an "appropriate adult" (something similar to that of the PEACE model in the United Kingdom), but voiced concerns about the importance of training and independence (more below). The most common theme referenced, is that an attorney, because of their training and expertise, can assist the juvenile defendant in making informed decisions. The vast majority of defense attorneys stated that they would advise their clients not to speak to the police, at least until after they had a chance to meet with the client and view the case. In this study, $57.9 \%$ of defense attorneys stated that there are situations where it is helpful to cooperate with the police; however, defense attorneys need to be 
involved in those discussions as they are in a better position to weigh the circumstances than their juvenile clients. This is relatable to the role of an appropriate adult in the United Kingdom, whose involvement in juvenile interrogations is to "assist them [juveniles] to communicate with the police whilst respecting their right to say nothing unless they want to... (Home Office, 1985, Code C, p. 82). In the context of juvenile interrogations, an independent adult with training, whether it be a defense attorney or "appropriate adult", can help juveniles navigate communicating and cooperating with the police.

Defense attorneys' active involvement is all the more important given recent research that found jurors are more willing to convict a juvenile defendant when a parent or attorney was present during the interrogation (Mindthoff, Malloy, \& Höhs, 2020). This research suggests that having an adult present legitimizes confession evidence at the trial level; making it all the more imperative to require defense attorneys to be present during the interrogation to act as a protective factor in that setting (e.g., advising their client on the best course of action), before a case advances to trial. This requirement could protect juveniles from making an unintelligent waiver and confession, which ultimately could contribute to a wrongful conviction.

\section{Policy Implications}

While there was broad support of a policy requiring defense attorney presence in the interrogation room, defense attorneys also raised some logistical challenges that are beneficial for policy and practice to consider. Some of these concerns center around the feasibility of getting an attorney on-site (precinct, patrol car, school), particularly in the later hours of the evenings. Attorneys suggested having an attorney "on call" for a window of time to represent juveniles during questioning (similar to a warrant judge), which would alleviate $5^{\text {th }}$ Amendment concerns. Or requiring a "cool down" period, where juveniles cannot be questioned for a period 
of time (e.g., 24 hours), which would allow them time to speak to an attorney and reduce some of the situational pressures. Some of these issues could be ameliorated by instituting a policy of having trained individuals serve as an 'appropriate adult' assisting in the interrogation. This would add in a level of protection for juveniles, and allow the defense attorney time to consult with their client. Across the globe (United Kingdom, Australia, Canada, New Zealand, and Denmark), ‘appropriate adults', 'responsible persons', or 'independent persons' are used in interrogations for vulnerable persons (Pierpoint, 2008).

In the United Kingdom, a distinction is made between appropriate adults and legal representatives; one serves to protect the vulnerable person (appropriate adult), and the other to help guide them through the legal system (legal representative). In the United States, a similar system could be devised whereas these two individuals work together, but with different functions: the 'appropriate adult' serving to protect the juvenile and ease some of the situational pressures, and the defense attorney focusing on legal issues, rights, and advising their client on potential options/avenues. Additionally, having an 'appropriate adult' on call, could also decrease the amount of time an individual is detained, which is important for juveniles due to their dependency and vulnerabilities (Pierpoint, 2008). Overall, there are benefits to having 'appropriate adults' assist in the interrogation room. Based on these data and other research (presented above), an independent (non-parent), trained individual is likely to provide the most effective safeguard. Importantly, an 'appropriate adult' serves a distinct purpose from the attorney, and research and policy should consider how these individuals could work in conjunction with defense attorneys.

Other suggestions from defense attorneys in this sample included switching the burden of proof requirements, such that the prosecution would be required to prove that statements should 
be admissible, and implementing specialized training for youth attorneys. All of these suggestions represent fruitful areas for research to examine; for example, how these policies might work, how feasible they would be, and the benefits and fallbacks.

\section{Limitations and Future Directions}

While this study advances our understanding of juvenile interrogations, it does come with its limitations. First, in this study, we had a relatively low response rate (albeit not abnormal for studies involving defense attorneys), which yielded a sample of only 19 defense attorney participants. This sample was sufficient to reach saturation, covering the patterns, categories, and variety of responses (Moser \& Korstjens, 2018); but, the findings from these data are not generalizable in the similar standard of quantitative research. In quantitative research, data may be generalizable due to the large sample size and sample demographics; in qualitative research, data may be generalizable if the themes generated are transferable to other unique samples (e.g., other juvenile attorneys), although the specific content of the themes may differ (Korstjens \& Moser, 2018; Morse, 1999). Important for the interpretation of these data, the themes presented, while informative of juvenile attorneys' experiences and thoughts on safeguards in the interrogation room, are not directly generalizable to all juvenile attorneys or jurisdictions (e.g., attorneys practicing in rural jurisdictions, or jurisdictions with an already established policy of attorney/'appropriate adult' presence).

Second, in this study, we were only able to capture the responses of those who voluntarily chose to participate, therefore could be those most interested in juvenile justice reform (for example). Similarly, we used a snowball sampling strategy (supplemental to email requests) to solicit participation, which injects non-randomness into our sample. And lastly, while defense attorneys were reminded that their responses were anonymous, and interview 
questions were not specific to cases, it is possible that some might have been hesitant to speak about experiences in the interrogation room. These factors are important caveats to consider of the data and results presented here.

In this study, we focused exclusively on defense attorneys due to their proximity and role with juveniles in the legal system, and because their presence/involvement (through mandated policy) has been highlighted as a suggestion for reform (Alberts, 2016). Future research could benefit by interviewing all parties involved to get at the triangulation of this issue; for example, interviewing police and juveniles regarding the defense attorneys' presence and impact. While this methodological approach would be difficult, and there would be additional concerns regarding confidentiality and attorney-client privilege, this type of work could extend our understanding of juvenile interrogations immensely.

\section{Conclusion}

Requiring defense attorneys in the interrogation room has been highlighted for years as a recommendation for protecting juveniles (Alberts, 2016), and some jurisdictions have implemented laws enacting this type of policy. This study sought to explore this topic further, particularly from the perspective of defense attorneys who are tasked with protecting their juvenile clients' rights. Defense attorneys cited juvenile suggestibility, less developed brains, and socialization to follow what an authority figure says, as justifications for increased protections for youth in comparison to adults. One of the main differences illustrated by defense attorneys was that youth do not take into account the long-term consequences of waiving their rights, rather they are concerned with their present situation (being questioned by police). Of the attorneys interviewed, most reported never have been present for a juvenile interrogation, while others reported rarely being present. This demonstrates that youth defendants are frequently 
waiving their right to an attorney. The overwhelming majority of participants stated that requiring a defense attorney to be present in the interrogation room or when youth are being questioned by police is a necessary protective factor. 


\section{References}

Alberts, J. (2016). Interrogation of juveniles. Are parents the best defenders of juveniles' right to remain silent? New Criminal Law Review: An International and Interdisciplinary Journal, 19(1), 109-124.

American Bar Association (2013). The Impact of National Standards on Juvenile Defense Practice. Retrieved from https://www.americanbar.org/groups/public_interest/child_law/resources/child_law_pract iceonline/child_law_practice/vol_32/june-2013/the-impact-of-national-standards-onjuvenile-defense-practice/

America's Addiction to Juvenile Incarceration: State by state. (n.d.). American Civil Liberties Union. Retrieved from https://www.aclu.org/

Braun, V., \& Clarke, V. (2006). Using thematic analysis in psychology. Qualitative Research in Psychology, 3(2), 77-101.

Burns, K., Burns, S. McMahon, D., \& Florentine Films, production company (2012). The Central Park five (The PBS Video Collection, Second Edition). Arlington, VA: Public Broadcasting Service (PBS).

Cleary, H., \& Warner, T. (2016). Police training in interviewing and interrogation methods: A comparison of techniques used with adult and juvenile suspects. Law and Human Behavior, 40(3), 270-284.

Custodial Interrogation: Juveniles, Cal. 395 Welfare and Institutions Code $§ 625.6$ (2017).

Exoneration Anniversary: Central Park Five (2012, December 12). Retrieved from https://www.innocenceproject.org/exoneration-anniversary-central-park-five/

Escobedo v. Illinois, 378 U.S. 478 (1964). 
False Confessions More Prevalent Among Teens. (2013, September 9). The Innocence Project. Retrieved from https://www.innocenceproject.org/

Feld, B. (2006). Police interrogation of juveniles: An Empirical Study of Policy and Practice. The Journal of Criminal Law and Criminology (1973-), 97(1), 219-316.

Feld, B., \& Project Muse. (2012). Kids, cops, and confessions inside the interrogation room (UPCC book collections on Project MUSE). New York: New York University Press.

Freedman, S., Eastwood, J., Snook, B., \& Luther, K. (2014). Safeguarding Youth Interrogation Rights: The Effect of Grade Level and Reading Complexity of Youth Waiver Forms on the Comprehension of Legal Rights. Applied Cognitive Psychology, 28, 427-431. DOI: 10.1002/acp.3001

Gardner, M., \& Steinberg, L. (2005). Peer influence on risk taking, risk preference, and risky decision making in adolescence and adulthood: An experimental study. Developmental Psychology, 41(4), 625-635.

Grisso, T., Steinberg, L., \& Woolard, et al. (2003). Juveniles' competence to stand trial: A comparison of adolescents' and adults' capabilities as trial defendants. Law and Human Behavior, 27, 333-363. DOI: 10.1023/A:1024065015717

Gudjonsson, G. H. (2018). The psychology of false confessions. Forty years of science and practice. Chichester: Wiley Blackwell.

Gudjonsson, G. H., \& Pearse, J. (2011). Suspect interviews and false confessions. Current Directions in Psychological Science, 20(1), 33-37. doi:10.1177/0963721410396824

Gudjonsson, G. H., Sigurdsson, J. F., Bragason, O. O., Newton, A. K., \& Einarsson, E. (2008). Interrogative suggestibility, compliance and false confessions among prisoners and their 
relationship with attention deficit hyperactivity disorder (ADHD) symptoms. Psychological Medicine, 38, 1037-1044. doi:10.1017/S0033291708002882

Gudjonsson, G. H., Sigurdsson, J. F., Sigfusdottir, I. D., Asgeirsdottir, B. B., González, R.A., \& Young, S. (2016). A national epidemiological study investigating risk factors for police interrogation and false confession among juveniles and young persons. Social Psychiatry and Psychiatric Epidemiology, 51(3), 359-67. doi: 10.1007/s00127-015-1145-8.

Henning, K. (2006). It takes a lawyer to raise a child? Allocating responsibilities among parents, children, and lawyers in delinquency cases. Nevada Law Journal, 6(3), 836-889. http://scholarship.law.georgetown.edu/facpub/87

Home Office (1985). Police and Criminal Evidence Act 1984. London: HMSO. Retrieved from https://assets.publishing.service.gov.uk/government/uploads/system/uploads/attachment_ data/file/729842/pace-code-c-2018.pdf

In re Gault, 387 U.S. 1 (1967).

Inbau, F., Reid, J., Buckley, J., \& Jayne, B. (2001). Criminal interrogation and confessions ( $\left.4^{\text {thed. }}\right)$. Gaithersburg, MD: Aspen.

J.D.B. v. North Carolina, 564 U.S. 261 (2011).

Kassin, S. M. (2014). False confessions: Causes, consequences, and implications for reform. Policy Insights from the Behavioral and Brain Sciences, 1(1), 112121. https://doi.org/10.1177/2372732214548678

Kassin, S. M., Drizin, S. A., Grisso, T., Gudjonsson, G. H., Leo, R. A., \& Redlich, A. D. (2010). Police-induced confessions: Risk factors and recommendations. Law and Human Behavior, 34(1), 3-38. doi:10.1007/s10979-009-9188-6 
King, L. \& Snook, B. (2009). Peering inside a Canadian interrogation room: An examination of the Reid model of interrogation, influence tactics, and coercive strategies. Criminal Justice \& Behavior, 36(7), 674-694. DOI: 10.1177/0093854809335142

Korstjens, I. \& Moser, A. (2018). Series: Practical guidance to qualitative research. Part 4: Trustworthiness and publishing. European Journal of General Practice, 24(1), 120-124. DOI: $10.1080 / 13814788.2017 .1375092$

Leo, R. A. (1996). Inside the interrogation room. Journal of Criminal Law and Criminology, 86, 266-303. doi: $10.2307 / 1144028$

Miranda v. Arizona, 384 U.S. 436 (1966).

Medford, S., Gudjonsson, G.H. and Pearse, J. (2003). The efficacy of the appropriate adult safeguard during police interviewing. Legal and Criminological Psychology, 8, 253-266. doi: $10.1348 / 135532503322363022$

Meyer, J. R. \& Reppucci, N. D. (2007). Police practices and perceptions regarding juvenile interrogation and interrogative suggestibility. Behavioral Sciences and the Law, 25, 757780. doi: $10.1002 / \mathrm{bs} 1.774$

Miller v. Alabama, 132 S.Ct. 2455 (2012).

Mindthoff, A., Malloy, L. C., \& Höhs, J. M. (2020). Mock jurors’ perceptions and case decisions following a juvenile interrogation: Investigating the roles of interested adults and confession type. Law and Human Behavior, 44(3), 209222. https://doi.org/10.1037/1hb0000371

Morse, J. M. (1999). Qualitative Generalizability. Qualitative Health Research, 9(1), 5-6. https://doi.org/10.1177/104973299129121622 
Moser, A. \& Korstjens, I. (2018). Series: Practical guidance to qualitative research. Part 3: Sampling, data collection and analysis, European Journal of General Practice, 24(1), 918. DOI: $10.1080 / 13814788.2017 .1375091$

National Juvenile Defender Center (2020). Advancing Youth Justice: An Assessment of Access to and Quality of Juvenile Defense Counsel in Oregon. Retrieved from https://njdc.info/wp-content/uploads/Oregon-Assessment-Web.pdf

NeMoyer, A., Kelley, S., Zelle, H., \& Goldstein, N. E. (2018). Attorney perspectives on juvenile and adult clients' competence to plead guilty. Psychology, Public Policy, and Law, 24(2), 171.

Owen-Kostelnik, J., Reppucci, N., \& Meyer, J. (2006). Testimony and Interrogation of Minors: Assumptions about Maturity and Morality. American Psychologist, 61(4), 286-304.

Patton, M. P. (2015). Qualitative Research and Evaluation Methods. 4th Edition, Sage Publications, Thousand Oak.

Pearse, J. \& Gudjonsson, G. (1997). Police interviewing and legal representation: A field study, The Journal of Forensic Psychiatry, 8(1), 200208. DOI: $\underline{10.1080 / 09585189708412005}$

Pierpoint, H. (2008). Quickening the PACE? The use of volunteers as appropriate adults in England and Wales. Policing \& Society, 18(4), 397-410, DOI:10.1080/10439460802094678

Public Act 099-082, Ill. 705 Comp. Stat. Ann. 405/5-170 (2017).

Redlich, A., \& Goodman, D. (2003). Taking responsibility for an act not committed: The influence of age and suggestibility. Law and Human Behavior, 27(2), 141-156. 
Redlich, A. D., Silverman, M., Chen, J., \& Steiner, H. (2004). The police interrogation of children and adolescents. In Interrogations, confessions, and entrapment (pp. 107-125). Springer, Boston, MA.

Relating to rights of youth in custodial interviews by peace officers, Ore. HB 2718 (2017).

Robin, Gerald D. (1982). Juvenile interrogation and confessions. Journal of Police Science and Administration, 10(2), 224-228.

Rogers, R., Hazelwood, L., Sewell, K., Shuman, D., \& Blackwood, H. (2008). The comprehensibility and content of juvenile Miranda warnings. Psychology, Public Policy, and Law, 14(1), 63-87.

Shawyer, A., Milne, B., \& Bull, R. (2009). Investigative interviewing in the UK. In T.

Williamson, B. Milne, \& R. Bull (Eds.), International developments in investigative interviewing (p. 24-38). Devon, England: Willan.

Steinberg, L. (2007). Risk taking in adolescence: New perspectives from brain and behavioral science. Current Direction in Psychological Science, 16(2), 55-59. https://psycnet.apa.org/doi/10.1111/j.1467-8721.2007.00475.x

Strauss, A., \& Corbin, J. (1998). Basics of qualitative research: Techniques and procedures for developing grounded theory (2nd ed.). Sage Publications, Inc.

Urbanized Areas and Urban Clusters: 2010. (2010). Retrieved from United States Census Bureau website: https://www2.census.gov/geo/pdfs/mapsdata/maps/reference/2010UAUC_List.pdf

U.S. Department of Labor (2019). Employed persons by detailed occupation, sex, race, and Hispanic or Latino ethnicity. Retrieved from https://www.bls.gov/cps/cpsaat11.pdf 
Viljoen, J., Klaver, L., \& Roesch, J. (2005). Legal decisions of preadolescent and adolescent defendants: Predictors of confessions, pleas, communication with attorneys, and appeals. Law and Human Behavior, 29(3), 253-277.

Viljoen, J., \& Roesch, L. (2005). Competence to waive interrogation rights and adjudicative competence in adolescent defendants: Cognitive development, attorney contact, and psychological symptoms. Law and Human Behavior, 29(6), 723-742.

DOI:10.1007/s10979-005-7978-y

Young, S., Moss, D., Sedgwick, O., Fridman, M., \& Hodgkins, P. (2015). A meta-analysis of the prevalence of attention deficit hyperactivity disorder in incarcerated populations.

Psychological Medicine, 45, 247-258. doi:10.1017/S0033291714000762 
Table 1. Final Themes with Corresponding Codes

\begin{tabular}{|c|c|c|c|c|c|c|c|}
\hline Themes & & & & Codes & & & \\
\hline $\begin{array}{l}\text { Situational } \\
\text { Factors }\end{array}$ & Time pressure & $\begin{array}{l}\text { Severity of } \\
\text { charges }\end{array}$ & Location & $\begin{array}{l}\text { Circumstances } \\
\text { around case }\end{array}$ & $\begin{array}{l}\text { Youth } \\
\text { questioned at } \\
\text { school }\end{array}$ & & \\
\hline \multirow{3}{*}{$\begin{array}{l}\text { Dispositional } \\
\text { Youth } \\
\text { Susceptibility } \\
\text { Factors }\end{array}$} & $\begin{array}{l}\text { Say what they } \\
\text { need to leave }\end{array}$ & $\begin{array}{l}\text { Don't realize } \\
\text { consequences }\end{array}$ & $\begin{array}{l}\text { Haven't } \\
\text { received } \\
\text { advice }\end{array}$ & $\begin{array}{l}\text { Not confident } \\
\text { asserting } \\
\text { rights }\end{array}$ & $\begin{array}{l}\text { Hard to make } \\
\text { informed } \\
\text { decision }\end{array}$ & $\begin{array}{l}\text { Power } \\
\text { dynamic }\end{array}$ & $\begin{array}{l}\text { Youth } \\
\text { conditioned/ } \\
\text { socialized/ } \\
\text { Teach kids to } \\
\text { be honest with } \\
\text { LE }\end{array}$ \\
\hline & $\begin{array}{l}\text { Youth feel } \\
\text { they have to } \\
\text { talk to LE }\end{array}$ & $\begin{array}{l}\text { Youth in } \\
\text { system often } \\
\text { had trauma }\end{array}$ & $\begin{array}{l}\text { Youth lack } \\
\text { maturity }\end{array}$ & $\begin{array}{l}\text { Reasoning } \\
\text { ability/ Mental } \\
\text { capacity }\end{array}$ & $\begin{array}{l}\text { Autonomy to } \\
\text { make } \\
\text { decisions }\end{array}$ & $\begin{array}{l}\text { Brains aren't } \\
\text { fully } \\
\text { developed }\end{array}$ & Impulsivity \\
\hline & Suggestibility & $\begin{array}{l}\text { Racial/ Ethnic } \\
\text { differences }\end{array}$ & Less educated & $\begin{array}{l}\text { Youth don't } \\
\text { understand } \\
\text { warnings }\end{array}$ & $\begin{array}{l}\text { Age } \\
\text { differences }\end{array}$ & $\begin{array}{l}\text { Youth don't } \\
\text { understand } \\
\text { legal nuances }\end{array}$ & \\
\hline \multirow{2}{*}{$\begin{array}{l}\text { Parental } \\
\text { Impact }\end{array}$} & $\begin{array}{l}\text { Parents can be } \\
\text { helpful }\end{array}$ & $\begin{array}{l}\text { Parents don't } \\
\text { understand }\end{array}$ & $\begin{array}{l}\text { Parents } \\
\text { encourage } \\
\text { truth }\end{array}$ & $\begin{array}{l}\text { Parents have } \\
\text { own interests } \\
\text { in mind }\end{array}$ & $\begin{array}{l}\text { Parents hurt } \\
\text { youths' cases }\end{array}$ & $\begin{array}{l}\text { Parents often } \\
\text { present }\end{array}$ & $\begin{array}{l}\text { Parents } \\
\text { sometimes } \\
\text { present }\end{array}$ \\
\hline & $\begin{array}{l}\text { Parents are not } \\
\text { often present }\end{array}$ & $\begin{array}{l}\text { Attorney and } \\
\text { parent have } \\
\text { different roles }\end{array}$ & & & & & \\
\hline \multirow{2}{*}{$\begin{array}{l}\text { Requiring } \\
\text { Attorneys }\end{array}$} & $\begin{array}{l}\text { Tells client not } \\
\text { to speak with } \\
\text { police }\end{array}$ & $\begin{array}{l}\text { Require atty, } \\
\text { less waivers }\end{array}$ & $\begin{array}{l}\text { Defense } \\
\text { attorney } \\
\text { protect clients' } \\
\text { rights }\end{array}$ & $\begin{array}{l}\text { Empower } \\
\text { youth to make } \\
\text { informed } \\
\text { decisions }\end{array}$ & $\begin{array}{l}\text { Wait to speak } \\
\text { with LE }\end{array}$ & $\begin{array}{l}\text { More } \\
\text { statements } \\
\text { without } \\
\text { attorney }\end{array}$ & $\begin{array}{l}\text { Have youth } \\
\text { evaluated/ } \\
\text { expert } \\
\text { testimony }\end{array}$ \\
\hline & $\begin{array}{l}\text { Important to } \\
\text { earn trust of } \\
\text { youth }\end{array}$ & $\begin{array}{l}\text { Important to } \\
\text { follow through } \\
\text { with youth }\end{array}$ & $\begin{array}{l}\text { Suppress } \\
\text { statements }\end{array}$ & $\begin{array}{l}\text { Private } \\
\text { attorney in } \\
\text { contact sooner }\end{array}$ & $\begin{array}{l}\text { Court } \\
\text { appointed } \\
\text { contact later }\end{array}$ & $\begin{array}{l}\text { Atty allow } \\
\text { youth to speak } \\
\text { in structured } \\
\text { interview }\end{array}$ & $\begin{array}{l}\text { Atty } \\
\text { explanation } \\
\text { helps } \\
\text { understanding }\end{array}$ \\
\hline
\end{tabular}




\begin{tabular}{|c|c|c|c|c|c|c|c|}
\hline & $\begin{array}{l}\text { Atty rarely } \\
\text { present for } \\
\text { questioning }\end{array}$ & $\begin{array}{l}\text { Attorney } \\
\text { consult is } \\
\text { helpful }\end{array}$ & $\begin{array}{l}\text { Atty protects } \\
\text { client from } \\
\text { charges }\end{array}$ & $\begin{array}{l}\text { Attorney } \\
\text { allows youth } \\
\text { to make } \\
\text { informed } \\
\text { decision }\end{array}$ & $\begin{array}{l}\text { Never been } \\
\text { present } \\
\text { interrogation }\end{array}$ & $\begin{array}{l}\text { Atty job is } \\
\text { best legal } \\
\text { outcome }\end{array}$ & $\begin{array}{l}\text { First meet } \\
\text { after fact }\end{array}$ \\
\hline \multirow{2}{*}{$\begin{array}{l}\text { Law } \\
\text { Enforcement } \\
\text { Impact }\end{array}$} & $\begin{array}{l}\text { LE have } \\
\text { different } \\
\text { perspective }\end{array}$ & $\begin{array}{l}\text { LE isolate } \\
\text { youth from } \\
\text { parent }\end{array}$ & $\begin{array}{l}\text { Speaking with } \\
\text { LE could } \\
\text { benefit youth }\end{array}$ & $\begin{array}{l}\text { Speak to } \\
\text { police to find } \\
\text { out their } \\
\text { intentions }\end{array}$ & $\begin{array}{l}\text { Speaking with } \\
\text { police doesn't } \\
\text { benefit }\end{array}$ & & \\
\hline & $\begin{array}{l}\text { Interrogation } \\
\text { tactics }\end{array}$ & $\begin{array}{l}\text { Authority } \\
\text { figure/ respect } \\
\text { authority }\end{array}$ & $\begin{array}{l}\text { Police } \\
\text { influence } \\
\text { (authority) }\end{array}$ & & & & \\
\hline \multirow{3}{*}{$\begin{array}{l}\text { Opinions on } \\
\text { Safeguards }\end{array}$} & $\begin{array}{l}\text { Videotaping } \\
\text { beneficial/ } \\
\text { helpful after } \\
\text { fact }\end{array}$ & $\begin{array}{l}\text { Uncertain } \\
\text { about neutral } \\
\text { adult }\end{array}$ & $\begin{array}{l}\text { Any trusted } \\
\text { adult present } \\
\text { benefits }\end{array}$ & $\begin{array}{l}\text { More time to } \\
\text { decide on } \\
\text { waiver }\end{array}$ & $\begin{array}{l}\text { Neutral adult } \\
\text { may be helpful }\end{array}$ & $\begin{array}{l}\text { Specialized } \\
\text { youth atty } \\
\text { training }\end{array}$ & $\begin{array}{l}\text { Neutral adult } \\
\text { may } \\
\text { encourage } \\
\text { truth }\end{array}$ \\
\hline & $\begin{array}{l}\text { Youth level } \\
\text { warnings }\end{array}$ & $\begin{array}{l}\text { Officer } \\
\text { explanation } \\
\text { may be helpful }\end{array}$ & Case law issue & $\begin{array}{l}\text { Body cams } \\
\text { helpful }\end{array}$ & $\begin{array}{l}\text { Have attys on } \\
\text { call }\end{array}$ & $\begin{array}{l}\text { Defense } \\
\text { attorneys need } \\
\text { more support }\end{array}$ & $\begin{array}{l}\text { Create statute } \\
\text { to make juv } \\
\text { statements } \\
\text { inadmissible }\end{array}$ \\
\hline & $\begin{array}{l}\text { Preventative } \\
\text { talking in } \\
\text { schools helps }\end{array}$ & $\begin{array}{l}\text { Parental } \\
\text { consent for } \\
\text { questioning }\end{array}$ & $\begin{array}{l}\text { Require atty is } \\
\text { too costly }\end{array}$ & $\begin{array}{l}\text { Support } \\
\text { defense } \\
\text { attorney } \\
\text { present }\end{array}$ & & & \\
\hline \multirow{2}{*}{$\begin{array}{l}\text { Waiver } \\
\text { Competency }\end{array}$} & $\begin{array}{l}\text { Admissions } \\
\text { often made/ } \\
\text { right to atty } \\
\text { often waived }\end{array}$ & $\begin{array}{l}\text { Less } \\
\text { statements the } \\
\text { better }\end{array}$ & $\begin{array}{l}\text { Always make } \\
\text { admission }\end{array}$ & $\begin{array}{l}\text { Youth aren't } \\
\text { competent to } \\
\text { waive }\end{array}$ & $\begin{array}{l}\text { Youth } \\
\text { competent to } \\
\text { waive }\end{array}$ & $\begin{array}{l}\text { Youth } \\
\text { unfamiliar } \\
\text { with attorney }\end{array}$ & $\begin{array}{l}\text { Youth familiar } \\
\text { with attorney }\end{array}$ \\
\hline & $\begin{array}{l}\text { Youth with } \\
\text { legal } \\
\text { experience } \\
\text { still confess }\end{array}$ & $\begin{array}{l}\text { Youth first } \\
\text { admit to } \\
\text { school }\end{array}$ & $\begin{array}{l}\text { Youth } \\
\text { sometimes } \\
\text { competent to } \\
\text { waive }\end{array}$ & & & & \\
\hline
\end{tabular}




\begin{tabular}{l|l|l|l|l|l}
\cline { 2 - 5 } $\begin{array}{l}\text { System } \\
\text { Impact }\end{array}$ & $\begin{array}{l}\text { False } \\
\text { confessions }\end{array}$ & $\begin{array}{l}\text { Treatment/ } \\
\text { process differs } \\
\text { in juvenile vs } \\
\text { adult court }\end{array}$ & $\begin{array}{l}\text { Issues with } \\
\text { how Miranda } \\
\text { is written }\end{array}$ & $\begin{array}{l}\text { System } \\
\text { stacked } \\
\text { against youth }\end{array}$ & \\
\hline
\end{tabular}

Note. Shading represents frequency of references to each code within a theme (i.e., the percent of participants who referenced that code in their interview).

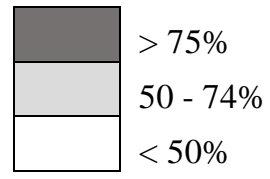


Table 2. Presence of Codes in Themes by Participant

\begin{tabular}{lcccccccc}
\hline $\begin{array}{l}\text { Participant } \\
\text { ID }\end{array}$ & $\begin{array}{c}\text { Situational } \\
\text { Factors }\end{array}$ & $\begin{array}{c}\text { Dispositional } \\
\text { Youth } \\
\text { Susceptibility } \\
\text { Factors }\end{array}$ & $\begin{array}{c}\text { Parental } \\
\text { Impact }\end{array}$ & $\begin{array}{c}\text { Requiring } \\
\text { Attorneys }\end{array}$ & $\begin{array}{c}\text { Law } \\
\text { Enforcement } \\
\text { Impact }\end{array}$ & $\begin{array}{c}\text { Opinions } \\
\text { on } \\
\text { Safeguards }\end{array}$ & $\begin{array}{c}\text { Waiver } \\
\text { Competency }\end{array}$ & $\begin{array}{c}\text { System } \\
\text { Impact }\end{array}$ \\
\hline P1 & 1 & 6 & 2 & 13 & 5 & 4 & 3 & 1 \\
P2 & 1 & 2 & 0 & 9 & 4 & 4 & 3 & 0 \\
P3 & 3 & 12 & 3 & 9 & 5 & 5 & 2 & 2 \\
P4 & 3 & 5 & 6 & 10 & 5 & 7 & 3 & 3 \\
P5 & 1 & 1 & 0 & 9 & 5 & 6 & 1 & 2 \\
P6 & 2 & 13 & 2 & 10 & 5 & 5 & 4 & 2 \\
P7 & 0 & 8 & 3 & 8 & 4 & 3 & 3 & 2 \\
P8 & 3 & 7 & 6 & 11 & 4 & 4 & 3 & 1 \\
P9 & 3 & 10 & 4 & 7 & 5 & 3 & 2 & 2 \\
P10 & 3 & 6 & 3 & 10 & 5 & 7 & 4 & 0 \\
P11 & 2 & 10 & 5 & 12 & 6 & 3 & 4 & 2 \\
P12 & 2 & 6 & 4 & 10 & 3 & 5 & 4 & 1 \\
P13 & 3 & 9 & 6 & 11 & 5 & 6 & 5 & 1 \\
P14 & 3 & 7 & 3 & 14 & 5 & 7 & 3 & 2 \\
P15 & 3 & 7 & 4 & 11 & 3 & 5 & 5 & 0 \\
P16 & 3 & 9 & 4 & 13 & 6 & 7 & 3 & 2 \\
P17 & 1 & 6 & 4 & 8 & 2 & 5 & 4 & 0 \\
P18 & 2 & 10 & 6 & 10 & 6 & 5 & 4 & 2 \\
P19 & 2 & 9 & 3 & 14 & 5 & 6 & 3 & 2 \\
\hline Total & 41 & 143 & 68 & 199 & 88 & 97 & 63 & 27 \\
\hline
\end{tabular}

Note. Frequency of themes referenced by each participant, and total frequency for the sample. 
Interview Questions

\section{Appendix Items}

1. In what percent of cases are you present in the interrogation room with a juvenile client?

2. In your experience, do juveniles make more or fewer statements to the police when you are present?

3. Based on your experience, do you think juveniles are competent enough to make an informed waiver of their rights?

a. Right to an attorney

i. In your experience, how often do they waive their right to an attorney in the interrogation room?

b. Right to remain silent

i. In your experience, how often do they waive their right to remain silent in the interrogation room?

4. Based on the experiences you've had, do you think an attorney in the interrogation room acts as a protective factor for juveniles? How?

a. Would requiring a defense attorney be different than the current standard of practice (where a juvenile has to request their attorney's presence)?

i. In terms of waiver of rights?

ii. In terms of juveniles' susceptibility to interrogation tactics?

5. If your juvenile client was considering waiving their $5^{\text {th }}$ Amendment right and confessing, how would you advise them?

6. Parents are sometimes present during the interrogation, which may be more hurtful to the juvenile's case than helpful. How is an "allied adult" in the interrogation room different than a parent? (e.g. Advocate provided by court with legal knowledge, an attorney)

Closing: Is there anything else you'd like to share about juveniles in the interrogation room and requiring an attorney to be present during the interrogation?

If Time Permits

1. In your experience, what are some factors that might influence juveniles' waiver of rights (e.g., age, location of questioning, parents)?

2. At what point are you typically brought in to assist with a juvenile client?

a. Has that been at the request of the juvenile (invoking their right to an attorney)? If not, who (how did that happen)?

3. From your standpoint (as the juvenile's advocate), what concerns do you have (if any) about your client talking with the police?

a. Does this usually help or hurt their case?

Demographics

1. What is your gender?

2. What is your race?

3. How many years have you been practicing law? 